\title{
Development of I-SETS Thematic Teaching Materials to Improve Student Character
}

\author{
Siti Munazilah, ${ }^{1}$ Agus Yulianto ${ }^{2}$ \\ ${ }^{1,2}$ Jurusan Fisika, Fakultas Matematika dan Ilmu Pengetahuan Alam, \\ Universitas Negeri Semarang
}

\begin{abstract}
The teaching material focuses on the theme of rain which is discussed through the I-SETS approach (Islamic, scientific, environmental, technological, and social). This study aimed to determine the characteristics, feasibility, and enchancement of student character after using teaching materials. This study uses the Research and Development (R \& D) method in the form of One Group Pretest-Post-test Design. Data collection techniques through interviews, observation, questionnaires, and test results. Data analysis techniques is quantitative descriptive. The characteristics of the teaching materials that had been developed were viewed from three aspects (content, presentation, and language). This characteristic is supported by validating the feasibility of teaching materials of $86.58 \%$ had very feasible criteria. Readability results reached a percentage of $53.20 \%$ in the appropriate category for students. The results of the application of teaching materials showed that there is no influence yet of teaching materials on the character development and integrated thinking skills which are based on the $\mathrm{N}$-gain test acquisition of 0.169 from the results of the character questionnaire, 0.218 from the results of the character observastions, 0.085 from pretest-posttest mark. This is due to obstacles when learning online and limited number of encounters.
\end{abstract}

Kata kunci: Teaching materials, thematic, I-SETS, characters.

\section{Pengembangan Bahan Ajar Tematik Berbasis I-SETS Untuk Meningkatkan Karakter Siswa}

\begin{abstract}
Abstrak
Bahan ajar tematik berfokus pada tema hujan yang dikupas melalui pendekatan I-SETS (Islam, sains, lingkungan, teknologi, dan sosial). Tujuan penelitian ini adalah mengetahui karakteristik, kelayakan, dan peningkatan karakter siswa setelah menggunakan bahan ajar. Penelitian ini menggunakan metode Research and Development (R \& D) dengan bentuk One Group Pretest-Post-test Design. Teknik pengumpulan data melalui wawancara, observasi, angket, dan hasil tes. Teknik analisis data berupa kuantitatif deskriptif. Karakteristik bahan ajar yang telah dikembangkan ditinjau dari tiga aspek, yaitu aspek isi, penyajian, dan bahasa didukung dengan hasil validasi kelayakan bahan ajar sebesar $86,58 \%$ pada kriteria sangat layak. Hasil keterbacaan sebesar 53,20\% pada kategori sesuai bagi siswa. Hasil penerapan bahan ajar menunjukkan bahwa belum nampak pengaruh bahan ajar terhadap
\end{abstract}


perkembangan karakter dan kemampuan berpikir terpadu yang didasarkan pada perolehan uji $\mathrm{N}$-gain sebesar 0,169 dari hasil angket karakter, 0,218 dari hasil observasi karakter dan 0,085 untuk nilai pretest ke posttest. Hal ini dikarenakan hambatan saat pembelajaran daring serta jumlah tatap muka yang terbatas.

Kata kunci: Bahan ajar, tematik, I-SETS, karakter.

\section{PENDAHULUAN}

Pendidikan merupakan pilar penting dalam pengembangan sumber daya manusia dan masyarakat. Indonesia sebagai negara berkembang terus mengupayakan peningkatan kualitas pendidikan demi tercapainya tujuan pendidikan nasional yang tercantum pada Undang-Undang Republik Indonesia Nomor 20 Tahun 2003 tentang Sistem Pendidikan Nasional pada Bab II Dasar, Fungsi dan Tujuan, pasal 3 bahwa pendidikan nasional berfungsi mengembangkan kemampuan dan membentuk watak serta peradaban bangsa yang bermartabat dalam rangka mencerdaskan kehidupan bangsa, bertujuan untuk berkembangnya potensi peserta didik agar menjadi manusia yang beriman dan bertakwa kepada Tuhan Yang Maha Esa, berakhlak mulia, sehat, berilmu, cakap, kreatif, mandiri, dan menjadi warga negara yang demokratis serta bertanggung jawab. Upaya peningkatan kualitas dilakukan melalui berbagai komponen pendidikan. Salah satunya pada bahan ajar, sebab bahan ajar yang beredar sebagian besar lebih memberatkan pada ringkasan materi, dan latihan soal sehingga kurang memperhatikan bentuk penerapan di kehidupan sehari-hari. Menurut hasil penelitian Khasanah (2015) solusi yang dapat mengatasi kelemahan sistem pembelajaran yang mengharuskan peserta didik mengejar penyelesaian materi pelajaran, tapi tidak memahami dengan jelas penerapan materi yang dipelajarinya pada kehidupan ialah pendidikan berbasis Sciene, Environment, Technology and Society yang kemudian disingkat menjadi SETS. Hal ini diperkuat dengan penelitian Qaimuddin (2018) yang menjelaskan bahwa pembelajaran bervisi SETS juga dapat meningkatkan peran aktif peserta didik dalam mencari solusi dari suatu masalah, selain itu juga dapat meningkatkan hasil belajar pada aspek kognitif, afektif, dan psikomotorik sesuai dengan tuntutan kurikulum 2013.

Selain bahan ajar yang mengajak siswa untuk mengkaji materi dengan memadukan pada unsur SETS, diperlukan pula bahan ajar yang memuat penanaman nilainilai karakter. Hal ini dibutuhkan supaya dapat mencapai tujuan pendidikan nasional dengan lebih optimal, selain itu pemuatan nilai-nilai karakter ini sejalan dengan 
karakteristik kurikulum 2013 yang tercantum pada Peraturan Menteri Pendidikan dan Kebudayaan Republik Indonesia Nomor 70 tahun 2013 dan diperkuat dengan adanya Peraturan Presiden Nomor 87 tahun 2017 tentang penguatan pendidikan karakter. Berdasarkan hal tersebut maka materi pembelajaran bukan hanya sekadar SETS namun perlu dikembangkan pembelajaran I-SETS (Islamic, Sciene, Environment, Technology and Society) guna menunjang nilai-nilai Islamic. Menurut hasil penelitian yang telah dilakukan oleh Rahmaniati \& Supramono (2015) bahwa pembelajaran dengan menggunakan pendekatan I-SETS menjadikan peserta didik semakin mudah memahami materi pelajaran, peka terhadap permasalahan yang ada di masyarakat, serta dapat mengambil solusi atau tindakan dari suatu masalah dan dapat mengaitkannya ke dalam nilai-nilai islam. Beberapa penelitian menyebutkan bahwa bahan ajar dengan pendekatan I-SETS dapat meningkatkan karakter peserta didik. Bahan ajar fisika yang menggunakan pendekatan I-SETS dapat mudah dipahami peserta didik serta mampu meningkatkan karakter peserta didik (Wahyuni et al., 2017). Senada dengan hal tersebut, berdasarkan penelitian Kusjuriansah \& Yulianto (2019) bahan ajar fisika berbasis I-SETS terkomplementasi karakter yang dapat membantu peserta didik supaya lebih memahami materi dalam kaitannya dengan I-SETS dan nilai-nilai karakter. Penelitian tersebut mengembangkan suatu bahan ajar pada mata pelajaran fisika, dimana fisika merupakan salah satu cabang dari Ilmu Pengetahuan Alam (IPA) yang mempelajari mengenai fenomena alam yang sesuai jika didekati dengan aspek I-SETS. Hal ini didasarkan pada hakikat IPA yang merupakan suatu kumpulan teori yang sistematis, bermula dari suatu observasi maupun eksperimen dengan menuntut sikap ilmiah pada gejala-gejala alam yang terjadi, dengan memperhatikan keteraturan di alam maka semakin meningkatkan keyakinan akan adanya kekuatan yang Maha Besar dan Maha Pengatur (Trianto, 2010, p. 138).

Hujan sebagai fenomena alam dalam kehidupan sehari-hari menjadi menarik untuk dibahas, sebab hujan dalam pendekatannya dalam digali dari unsur I-SETS. Pada sisi sains hujan menjadi objek pengetahuan yang dapat diamati dari kacamata fisika, kimia maupun biologi. Tema hujan dalam pendekatan Islamic juga mengandung banyak hikmah. Hikmah yang terkandung juga sejalan dengan pendekatan ilmu pengetahuan, diantaranya bagaimana angin menggerakkan awan, hingga awan bergumpal-gumpal, hujan turun di antara celah-celahnya, dan dari air hujan itu menjadi sumber bagi 
kehidupan. Fenomena kilat yang menyertai saat terjadinya hujan juga dapat dibedah pula dari sisi fisika dan islamic. Pada pendekatan islamic, kilat memberikan hikmah untuk senantiasa berharap dan berlindung kepada Allah.

Berdasarkan uraian di atas telah dilakukan penelitian berjudul "Pengembangan Bahan Ajar Tematik Berbasis I-SETS (Islamic, Sciene, Environment, Technology and Society) untuk Meningkatkan Karakter Siswa" yang memiliki tujuan (1) mendeskripsikan karakteristik bahan ajar tematik berbasis I-SETS yang dikembangkan sendiri oleh penulis, (2) menganalisis kelayakan bahan ajar tematik berbasis I-SETS, (3) menganalisis peningkatan karakter peserta didik sebelum dan sesudah menggunakan bahan ajar.

\section{METODE PENELITIAN}

Penelitian ini menggunakan metode Research and Development (R \& D). Bentuk desain uji coba yang digunakan ialah Pre-Experimental Design dengan mengambil One Group Pretest-Post-test Design yaitu suatu bentuk desain penelitian dimana suatu kelompok diberikan perlakuan, sebelum diberikan perlakuan terdapat pretest, dan selanjutnya dilakukan post-test guna mengetahui hasil pemberian perlakuan. Tahapan penelitian terdiri dari lima langkah yaitu perencanaan, pengembangan, validasi, revisi, dan uji coba (Sugiyono, 2017). Tahap perencanaan dimulai dengan wawancara ke guru IPA di sekolah mengenai lingkungan, kurikulum, dan bahan ajar yang digunakan. Informasi yang terhimpun digunakan dalam perencanaan desain bahan ajar, penyesuaian dengan kompetensi dan indikator pembelajaran hingga pengembangan produk bahan ajar. Produk bahan ajar yang telah disusun kemudian divalidasi tingkat kelayakan dan keterbacaan bahan ajar. Saran dan masukan dari validator menjadi bahan pertimbangan pada tahap revisi produk. Bahan ajar yang telah direvisi kemudian diuji coba di lapangan untuk menganalisis peningkatan karakter siswa setelah menggunakan bahan ajar.

Instrumen penelitian terdiri dari tes tertulis yaitu tes rumpang untuk menguji tingkat keterbacaan dan soal uraian pretest postest untuk mengetahui kemampuan berpikir terpadu dari siswa, angket untuk menganalisa tingkat kelayakan bahan ajar dan peningkatan karakter, lembar observasi untuk mengamati karakter peserta didik.

Analisa kelayakan, keterbacaan, peningkatan karakter melalui angket dan lembar observasi menggunakan persamaan menurut Sudijono (2014, p. 43) ialah:

$$
P=\frac{f}{N} \times 100 \%
$$


Hasil dari nilai persentase memiliki kriteria penilaian tersendiri untuk tingkat kelayakan, keterbacaan, dan peningkatan karakter.

Kriteria kelayakan bahan ajar menurut (Akbar, 2013, p. 41) ditunjukkan pada Tabel 1.

Tabel 1. Klasifikasi Tingkat Kelayakan Bahan Ajar

\begin{tabular}{ll}
\hline Interval & Kriteria \\
\hline $85 \%<$ skor $\leq 100 \%$ & Sangat layak \\
$70 \%<$ skor $\leq 85 \%$ & Layak \\
$50 \%<$ skor $\leq 70 \%$ & Cukup layak \\
$1 \%<$ skor $\leq 50 \%$ & Tidak layak \\
\hline
\end{tabular}

Kriteria keterbacaan bahan ajar berdasarkan Rankin \& Culhane dalam Sabarua (2017) ialah sebagai berikut:

Tabel 2. Klasifikasi Keterbacaan Bahan Ajar

\begin{tabular}{ll}
\hline Interval & Kriteria \\
\hline Nilai $>60 \%$ & Bahan ajar mudah dipahami \\
$41 \% \leq$ nilai $\geq 60 \%$ & Bahan ajar sesuai bagi siswa \\
Nilai $\leq 40 \%$ & Bahan ajar sukar dipahami \\
\hline
\end{tabular}

Klasifikasi tingkat perkembangan karakter menurut kemendiknas dalam Wahyuni et al. (2017) ialah sebagai berikut:

Tabel 3. Klasifikasi Tingkat Perkembangan Karakter

\begin{tabular}{ll}
\hline Interval \% Skor & Kriteria \\
\hline $81,25 \% \leq$ skor $\leq 100 \%$ & Membudaya \\
$62,5 \% \leq$ skor $<81,25 \%$ & Mulai berkembang \\
$43,75 \% \leq$ skor $<62,5 \%$ & Mulai terlihat \\
$25 \% \leq$ skor $<43,75 \%$ & Belum terlihat \\
\hline
\end{tabular}

Adapun kemampuan berpikir terpadu dari peserta didik dianalisis dari hasil soal pretest dan postest yang sebelumnya telah melalui telaah tingkat validasi, reliabel, daya beda, dan tingkat kesukarannya. Peningkatan hasil belajar dianalisis menggunakan rumus menurut Hake (1999):

$$
\langle g\rangle=\frac{\left\langle S_{\text {post }}\right\rangle-\left\langle S_{\text {pre }}\right\rangle}{100 \%-\left\langle S_{\text {pre }}\right\rangle}
$$

Kriteria tingkat gain menurut Hake (1999) yang diterapkan ditunjukkan Tabel 4 berikut ini:

Tabel 4. Klasifikasi Tingkat Uji Gain 


\begin{tabular}{ll}
\hline Interval & Kriteria \\
\hline $\mathrm{g} \leq 0,30$ & Rendah \\
$0,30<\mathrm{g} \leq 0,70$ & Sedang \\
$\mathrm{g}>0,70$ & Tinggi \\
\hline
\end{tabular}

\section{HASIL DAN PEMBAHASAN}

Tahapan pengembangan dan revisi menghasilkan produk bahan ajar yang siap digunakan dalam penelitian uji coba di sekolah. Bahan ajar tematik berbasis I-SETS dibuat menggunakan font Calibri ukuran 12 pt dengan ukuran A4, walaupun dalam penerapan di lapangan produk bahan ajar yang dikembangkan disebarkan secara softfile dikarenakan penelitian yang dimulai pada tanggal 15 April 2020 dilaksanakan secara online sebab MTs NU turut mengikuti anjuran pemerintah melaksanakan pembelajaran daring dalam masa darurat pencegahan Covid-19. Karakteristik bahan ajar dapat ditinjau dari tiga aspek yaitu aspek penyajian mengenai sistematika bahan ajar, aspek isi meliputi materi bahan ajar, dan aspek kebahasaan yang mencakup penggunaan bahasa yang komunikatif dan disesuaikan dengan kaidah Bahasa Indonesia yang baik dan benar. Bahan ajar disusun dengan sistematika, keruntutan pokok bahasan, dan kelengkapan penyajian yang baik. Produk akhir bahan ajar sendiri terbagi menjadi tiga bagian yaitu pendahuluan, isi, dan penutup. Bagian pendahuluan bahan ajar meliputi sampul buku, prakata, daftar isi, petunjuk penggunaan, kompetensi dasar dan indikator pencapaian kompetensi, peta konsep. Sampul buku disajikan dengan ilustrasi menarik yang mewakili bahan ajar dengan tema hujan. Pemilihan gambar tersebut sesuai dengan hakikat sampul yang menampilkan gambar pendukung bersesuaian dengan materi (Khairunnisa et al., 2018). Bagian isi berisi muatan materi tematik kajian hujan dengan keakuratan, keluasan, dan kedalaman yang baik. Materi dikupas dengan pendekatan I-SETS yang memadukan lima sisi yaitu Islamic, Science, Environment, Techonology, Society dan terintegrasi dengan muatan karakter religius, peduli terhadap lingkungan, dan peduli sosial. Sisi islamic tercermin pada segmen "mari berkelana mengkaji Al Qur'an". Siswa akan menemukan ayat-ayat dalam Al Qur'an dan hadits yang berkaitan dengan hujan, petir, dan air. Perpaduan ayat Al Qur'an dan hadits ke dalam bahan ajar diharapkan mampu meningkatkan karakter peserta didik, sebagaimana penelitian yang dilakukan oleh Ihwanudin et al. (2018) bahwa bahan ajar yang dilengkapi dengan ayat-ayat Al Qur'an mengenai fenomena alam dapat membuat pembelajaran menjadi menyenangkan dan meningkatkan karakter keislaman. Segmen "Mari berkelana mengenal lingkungan" 
mengajak siswa mengenal lingkungan dan menyelipkan nilai kepedulian terhadap lingkungan melalui fenomena efek rumah kaca, fenomena banjir, dan manfaat air. Segmen berkaitan dengan aspek society dikupas lebih mendalam pada "mari menjelajah di masyarakat" yang membedah dampak dan manfaat hujan di masyarakat. Hujan dan kaitannya dengan teknologi dibahas pada rubrik "mari menjelajah dunia teknologi" meliputi alat pengukur intensitas hujan, satelit, serta proses hujan buatan. Produk bahan ajar yang dikembangkan juga mengikuti kurikulum 2013 sehingga menyediakan segmen "asyiknya mencoba" untuk melatih kemampuan posikomotorik dari peserta didik. Muatan nilai-nilai karakter yang coba dikembangkan melalui segmen khusus "Yuk jadi sobat beriman dan sobat peduli”. Bahan ajar tematik juga didesain untuk mengajak siswa berpikir lebih terpadu, melihat hujan bukan sekadar kejadian alam biasa yang dikaji dari sains tapi juga membawa berkah dan manfaat bagi masyarakat luas, melihat dari sisi islamic menumbuhkan syukur, harap dan takut. Segmen berdiskusi pada "ayo berpikir terpadu" juga menyediakan ruang bagi siswa untuk membuat desain alat pelindung diri dari petir guna mengasah kemampuan mereka. Bagian penutup bahan ajar meliputi rangkuman, uji kompetensi, glosarium dan daftar pustaka.

Bahan ajar tematik berbasis I-SETS terintegrasi karakter yang dikembangkan diuji kelayakannya oleh 3 validator yang terdiri dari 2 Dosen Fisika UNNES dan 1 Guru IPA MTs. NU. Uji kelayakan bahan ajar dilakukan melalui angket dengan kriteria kelayakan berdasarkan aspek penilaian BSNP (2017) yang telah dimodifikasi yaitu meliputi aspek kelayakan isi, kelayakan penyajian, dan aspek kelayakan kebahasaan. Hasil uji kelayakan bahan ajar IPA berbasis I-SETS terintegrasi karakter disajikan pada Tabel 5.

Tabel 5. Hasil Uji Kelayakan Bahan Ajar

\begin{tabular}{lll}
\hline Aspek & Persentase(\%) & Kriteria \\
\hline Isi & $89,10 \%$ & Sangat Layak \\
Penyajian & $84,52 \%$ & Layak \\
Bahasa & $86,11 \%$ & Sangat Layak \\
Rata-rata & $86,58 \%$ & Sangat Layak \\
\hline
\end{tabular}

Tabel 5 menunjukkan bahan ajar berbasis I-SETS mendapatkan persentase sebesar $86,58 \%$ yang memenuhi kriteria sangat layak dan dapat digunakan dalam proses pembelajaran dengan beberapa perbaikan sesuai dengan saran dan masukan dari para validator. Uji keterbacaan bahan ajar dilakukan dengan teknik teks rumpang sebagai alat ukur. Teks rumpang tersebut disusun berdasarkan kutipan teks yang terdapat dalam bahan 
ajar terdiri dari 250-350 kata yang kemudian dilakukan penghilangan kata (delisi) sejumlah 50 kata dengan aturan melakukan penghilangan setiap kata ke-n, tanpa memperhatikan arti dan fungsi kata-kata yang dihilangkan, namun tidak berlaku jika jatuh pada kata bilangan (Sabarua, 2017). Uji keterbacaan bahan ajar ini dilakukan kepada peserta didik MTs NU kelas 7C dapat dilihat pada tabel 6 dibawah ini:

Tabel 6. Hasil Uji Keterbacaan

\begin{tabular}{llll}
\hline Responden & $\begin{array}{l}\text { Skor } \\
\text { Perolehan }\end{array}$ & Persentase & Kriteria \\
\hline S-1 & 23 & $46 \%$ & Sesuai bagi siswa \\
S-2 & 26 & $52 \%$ & Sesuai bagi siswa \\
S-3 & 28 & $56 \%$ & Sesuai bagi siswa \\
S-4 & 27 & $54 \%$ & Sesuai bagi siswa \\
S-5 & 25 & $50 \%$ & Sesuai bagi siswa \\
S-6 & 25 & $50 \%$ & Sesuai bagi siswa \\
S-7 & 31 & $62 \%$ & Mudah dipahami siswa \\
S-8 & 30 & $60 \%$ & Sesuai bagi siswa \\
S-9 & 29 & $58 \%$ & Sesuai bagi siswa \\
S-10 & 24 & $48 \%$ & Sesuai bagi siswa \\
S-11 & 27 & $54 \%$ & Sesuai bagi siswa \\
S-12 & 23 & $46 \%$ & Sesuai bagi siswa \\
S-13 & 26 & $52 \%$ & Sesuai bagi siswa \\
S-14 & 29 & $58 \%$ & Sesuai bagi siswa \\
S-15 & 26 & $52 \%$ & Sesuai bagi siswa \\
Rata-rata & 26,6 & $53,20 \%$ & Sesuai bagi siswa \\
\hline
\end{tabular}

Berdasarkan tabel 6 di atas dapat diuraikan bahwa jumlah peserta didik yang mengisi sebanyak 15 orang dan diperoleh skor persentase rata-rata sebesar 53,20\%. Hasil tersebut menunjukkan bahwa bahan ajar memenuhi kriteria sesuai untuk siswa.

Perkembangan karakter dari siswa dilihat melalui angket karakter pre-test dan post-test dan observasi. Hasil uji gain perkembangan karakter berdasarkan angket ialah sebagai berikut:

Tabel 7. Hasil Uji Gain Perkembangan Karakter berdasarkan Angket

\begin{tabular}{lllllll}
\hline Karakter & Sebelum & Kriteria & Setelah & Kriteria & $\begin{array}{l}\text { Hasil } \\
\text { Gain }\end{array}$ & $\begin{array}{l}\text { Uji } \\
\text { Kriteria } \\
\text { Gain }\end{array}$ \\
\hline $\begin{array}{l}\text { Religius } \\
\text { Peduli }\end{array}$ & $83,81 \%$ & Membudaya & $87,38 \%$ & Membudaya & 0,221 & Rendah \\
Lingkungan & $84,05 \%$ & Membudaya & $87,86 \%$ & Membudaya & 0,239 & Rendah \\
Peduli sosial & $84,29 \%$ & Membudaya & $85,00 \%$ & Membudaya & 0,045 & Rendah \\
Rata-rata & $84,05 \%$ & Membudaya & $86,75 \%$ & membudaya & 0,169 & Rendah \\
\hline
\end{tabular}

Berdasarkan tabel 7 dapat diungkapkan bahwa terjadi peningkatan nilai karakter dengan kriteria rendah setelah menggunakan media yang dikembangkan jika pengukuran melalui 
angket.

Media kedua untuk mengukur perkembangan karakter pada siswa ialah dengan observasi. Observasi dilakukan oleh tiga observer yang berasal dari mahasiswa jurusan fisika. Hasil perkembangan karakter melalui observasi tertera pada Tabel 8 .

Tabel 8.Hasil Uji Gain Perkembangan Karakter berdasarkan Observasi

\begin{tabular}{lllllll}
\hline Karakter & Sebelum & Kriteria & Setelah & Kriteria & $\begin{array}{l}\text { Hasil } \\
\text { Gain }\end{array}$ & $\begin{array}{l}\text { Uji } \\
\text { Griteria } \\
\text { Gain }\end{array}$ \\
\hline $\begin{array}{l}\text { Religius } \\
\text { Peduli }\end{array}$ & $83,07 \%$ & membudaya & $84,66 \%$ & Membudaya & 0,094 & Rendah \\
Lingkungan & $75,66 \%$ & $\begin{array}{l}\text { mulai } \\
\text { berkembang }\end{array}$ & $83,07 \%$ & Membudaya & 0,304 & Rendah \\
Peduli sosial & $79,37 \%$ & $\begin{array}{l}\text { mulai } \\
\text { berkembang }\end{array}$ & $85,19 \%$ & Membudaya & 0,282 & Rendah \\
Rata-rata & $79,37 \%$ & $\begin{array}{l}\text { mulai } \\
\text { berkembang }\end{array}$ & $83,86 \%$ & Membudaya & 0,218 & Rendah \\
\hline
\end{tabular}

Berdasarkan tabel 8 dapat diungkap bahwa melalui media observasi, rata-rata nilai karakter siswa mengalami peningkatan dengan kriteria rendah, namun nilai karakter tersebut telah tealh menjadi kebiasaan dari siswa atau dapat dikatakan membudaya.

Hasil angket dan observasi di atas menunjukkan bahwa belum nampak pengaruh yang signifikan. Hal ini dikarenakan untuk menumbuhkan karakter yang signifikan dibutuhkan proses yang panjang, dan berkelanjutan (Kemendiknas, 2010, p. 11). Proses yang panjang tersebut juga perlu didukung oleh orangtua, serta hal yang sangat penting ialah teladan langsung dari guru (Marzuki, 2015, pp. 41-42). Jika ditinjau dari proses pembentukan karakter menurut Lickona (1991, p. 51) yang terdiri dari memberi pengetahuan tentang kebaikan, menimbulkan komitmen, melakukan kebaikan, dan terbiasa melakukan kebaikan, maka pada penelitian ini dengan waktu yang singkat baru mencapai tahapan menimbulkan komitmen. Selain itu hasil tersebut juga dipengaruhi hambatan dan keterbatasan fasilitas saat pembelajaran online.

Peningkatan karakter tertinggi pada karakter peduli terhadap lingkungan yang berarti bahan ajar dengan pendekatan I-SETS terbukti mampu memberikan dampak pada siswa untuk mengaplikasikan materi dalam bentuk kepedulian terhadap lingkungan terutama pada penggunaan air dengan bijak. Hal ini sesuai dengan penelitian Khasanah (2015) yang menyebutkan bahwa jika konsep SETS diaplikasikan pada pembelajaran IPA maka dapat meningkatkan kehidupan yang lebih baik tanpa melupakan kelestarian lingkungan. Karakter religius juga mengalami peningkatan meskipun pada lembar observasi kurang terlihat. Peningkatan karakter religius ini sejalan dengan hasil penelitian 
dari Alamsah et al. (2013) yang menyebutkan bahwa pembelajaran sains dengan pendekatan I-SETS mampu meningkatkan rasa pengagungan terhadap Allah lewat ciptaannya.

Kemampuan berpikir terpadu dikembangkan melalui tes uraian berjumlah sepuluh soal yang mengacu pada indikator kemampuan berpikir terpadu yang dikemukakan oleh Marzano et al. (1988, pp. 103-105). Soal tersebut telah melalui tahap seleksi pada uji coba awal untuk dianalisa validitas butir, daya beda, tingkat kesukaran, dan reliabilitasnya. Soal yang memenuhi kriteria berjumlah 7 soal. Uji coba tes dilakukan melalui media google form. Media ini dipilih untuk memudahkan peserta didik dalam mengerjakan soal. Namun, penggunaan google form sebagai media tes juga memiliki kekurangan sebagaimana yang dijelaskan oleh Asniati (2019) yaitu penggunaan google form pada peserta didik dikhawatirkan akan meningkatkan tingkat kecurangan saat mengerjakan soal. Hasil uji gain rata-rata pretest dan post-test ditujukan pada Tabel 9.

Tabel 9.Hasil Uji Gain Pretest Post-test

\begin{tabular}{lcccc}
\hline \multicolumn{2}{c}{ Rata-Rata Nilai } & \multirow{2}{*}{$\begin{array}{c}\text { Hasil Uji } \\
\text { Gain }\end{array}$} & Kriteria \\
\cline { 1 - 2 } Pretest & Post-test & & 0,085 & Rendah \\
\hline 27,07 & 33,61 & & 0,05
\end{tabular}

Tabel 9 menunjukkan bahwa perolehan uji gain hanya sebesar 0,085 dengan kriteria rendah. Hal ini menunjukkan bahwa bahan ajar tematik berbasis I-SETS yang dikembangkan belum mampu untuk meningkatkan kemampuan berpikir terpadu secara optimal. Kemampuan berpikir terpadu yang diharapkan pada peserta didik ialah peserta didik mampu untuk mengaitkan tema hujan pada aspek kelimuan, dampaknya pada lingkungan, kebermanfaatannya pada masyarakat, kaitannya dengan aspek islam dan menambah rasa syukur pada diri peserta didik serta peserta didik mampu merancang sebuah teknologi pelindung diri dari petir. Kemampuan berpikir terpadu tersebut sudah coba dipandu selama pelaksanaan penelitian. Faktor yang mempengaruhi hasil penelitian diantaranya sikap siswa yang kurang bersungguh-sungguh dalam mengerjakan tes, bahan ajar yang dibagikan secara softfile sejalan dengan penelitian Utomo et al. (2015) bahwa bagi siswa yang tidak terbiasa dengan bacaan online, maka siswa cenderung tidak menyukai bahan ajar tersebut, soal uraian yang disusun berdasarkan indikator berpikir terpadu membuat siswa harus lebih memahami materi dan mengaitkan satu materi dengan materi yang lain 


\section{SIMPULAN}

Bahan ajar tematik dikembangkan dengan pendekatan I-SETS, yang mengupas hujan dari sisi sains, membahas dampak hujan terhadap lingkungan, mengantisipasi dampak buruk melalui teknologi supaya bermanfaat untuk masyarakat tanpa merusak alam, dan berpadu dengan ayat-ayat Al Qur'an dan hadits tentang hujan. Karaktersitik tersebut didukung dengan hasil uji kelayakan dengan persentase rata-rata sebesar $86,58 \%$ pada kriteria sangat layak dan keterbacaan diperoleh persentase sebesar 53,20\% pada kategori sesuai bagi siswa. Hasil analisa penerapan bahan ajar di MTs NU Ungaran menunjukkan bahwa bahan ajar belum memberi pengaruh yang signifikan bagi kemampuan berpikir terpadu dan peningkatan karakter religius, peduli lingkungan, dan peduli sosial ditunjukkan dari data hasil angket karakter dengan rata-rata nilai uji gain sebesar 0,169. Hasil observasi karakter dengan perolehan rata-rata nilai uji gain sebesar 0,218 dan hasil analisis uji gain sebesar 0,085 yang diperoleh dari nilai pretest-post-test. Saran yang dapat diberikan untuk penelitian-penelitian selanjutnya ialah (1) bahan ajar dapat dipadukan dengan video pembelajaran interaktif dengan memberikan tautan atau qr code pada bahan ajar, (2) hendaknya perlu diperhatikan kembali manajemen waktu dan pemilihan media pelaksanaan pembelajaran terutama jika penelitian dilakukan secara daring, (3) perlu dipertimbangkan media tes yang baik agar penelitian tidak berlangsung lama jika penelitian dilakukan secara daring, (4) pada penelitian selanjutnya yang sejenis, peneliti dapat merumuskan indikator observasi karakter yang lebih dapat dilihat, peneliti juga dapat menugaskan peserta didik untuk melakukan langsung pengamalan dari karakter yang ingin dicapai dan dibuktikan melalui gambar ataupun foto.

\section{DAFTAR PUSTAKA}

Akbar, S. (2013). Instrumen Perangkat Pembelajaran. Bandung : PT Remaja Rosdakarya.

Alamsah, M. A., Khanafiyah, S., \& Wiyanto. (2013). Penerapan Pendekatan SETS pada Pembelajaran Fsika untuk Meningkatkan Pengakuan terhadap Keagungan Sang Pencipta. Unnes Physics Education Journal, 2(3), 12-16.

Asniati, M. (2019). Pengembangan Instrumen Soal Literasi Sains Berbasis Google Form untuk Peserta didik SMP. Skripsi Universitas Islam Negeri Raden Intan Lampung. 
BSNP. (2017). Standar Buku Ajar dan Modul Ajar. Jakarta : Ristekdikti.

Hake, R. R. (1999). Analyzing Change/Gain Scores. American Educational Research Assosiation's Division D, Measurement, and Research Methodology, 1-4.

Ihwanudin, M., Astuti, B., \& Yulianto, A. (2018). Bahan Ajar IPA Terpadu Tipe Integrated Berbasis Komplementasi Ayat-Ayat Al-Quran. Unnes Physics Education Journal, 7(3), 36-42.

Kemendiknas. (2010). Pengembangan Pendidikan Budaya dan Karakter Bangsa. Jakarta: Balitbang.

Khairunnisa, H., Kamus, Z., \& Murtiani. (2018). Analisis Efektivitas Pengembangan Bahan Ajar Fisika Dengan Konten Kecerdasan Sosial Pada Materi Gerak Parabola , Gerak Melingkar Dan Hukum Newton Untuk Kelas X SMA . Pillar of Physics Education, 11(2), 121-128.

Khasanah, N. (2015). SETS ( Science , Environmental, Technology and Society ) sebagai Pendekatan Pembelajaran IPA Modern pada Kurikulum 2013. Seminar Nasional Konservasi Dan Pemanfaatan Sumber Daya Alam, 270-277.

Kusjuriansah, \& Yulianto, A. (2019). Pengembangan Bahan Ajar Fisika Berbasis ISETS Terkomplementasi Karakter Pada Materi Hukum Gravitasi Newton. Unnes Physics Education Journal, 8(2) : 120-132.

Lickona, T. (1991). Educating for Character: How Our Schools Can Teach Respect and Responsibility. US : The New York Times Company.

Marzano, J, R., Hughes, C. S., Jones, B. F., Rankin, S. C., \& Suhor, C. (1988). Dimension of Thinking a Framework For Curriculum and Instruction. Association for Supervision and Curriculum Development.

Marzuki. (2015). Pendidikan Karakter Islam. Jakarta : Amzah.

Qaimuddin. (2018). Pengembangan Perangkat Pembelajaran Bervisi SETS Biologi melalui Direct Instruction Berbasis Pemecahan Masalah terkait Kompetensi Pencemaran Lingkungan. Nuansa Jurnal Ilmiah Pendidikan, 6(2), 63-71.

Rahmaniati, R., \& Supramono. (2015). Pembelajaran I-SETS (Islamic, Environment, Technology, and Society) terhadap Hasil Belajar Peserta didik. Anterior Jurnal, 14(2), 194-200.

Sabarua, J. O. (2017). Implementasi Teknik Uji Rumpang pada Pembelajaran Bahasa Indonesia di Sekolah Dasar. 1-14. 
Sudijono, A. (2014). Pengantar Statistik Pendidikan. Jakarta: Grafindo Persada.

Sugiyono. (2017). Metode Penelitian Pendidikan (Pendekatan Kuantitatif, Kualitatif, dan $R \& D)$. Bandung : Alfabeta.

Trianto. (2010). Model Pembelajaran Terpadu: Konsep, Strategi, dan Implementasi dalam Kurikulum Tingkat Satuan Pendidikan. Jakarta : Bumi Aksara.

Utomo, D. S., Sumarmi, \& Susilo, S. (2015). Pengembangan Bahan Ajar E-Learning Berbasis Edmodo pada Materi Litosfer Kelas X SMA. Jurnal Pendidikan Geografi, 20(2), 1-8.

Wahyuni, A. I., Astuti, B., \& Yulianti, D. (2017). Bahan Ajar Fisika Berbasis I-SETS ( Islamic, Science, Environment, Technology ,. Unnes Physics Education Journal, 6(3), 17-25. 
Siti Munazilah, Agus Yulianto/ Phenomenon Vol. 11, No. 2, oktober 2021 